\title{
Despre necesitatea unei reforme curriculare periodice în ultrasonografie în România
}

Practica ultrasonografiei în România a înregistrat în ultimii 10 ani un trend ascendent, pe de o parte prin progresele tehnologice echipamentele ultrasonografice performante, prezente în număr din ce în ce mai mare în centrele de pregătire, dar și în importante unități medicale publice și private, pe de altă parte, prin activitatea științifică în domeniu - cursurile și conferințele organizate de SRUMB, publicațiile regăsite în Medical Ultrasonography, revista care și-a câștigat un binemeritat prestigiu, prin indexarea ISI și creșterea continuă a factorului de impact.

În acest trend ascendent se înscriu diversificarea aplicațiilor ultrasonografice performante într-un număr mare de centre, precum și preocupările Comitetului Director (CD) al SRUMB pentru reformarea curriculei de ultrasonografie pentru obținerea atestatului de studii complementare. Formarea practicienilor ecografiei dintr-un număr mare de specialități, un proces îndelungat, continuu, a început în primii ani 90, inițial în 3 - 4 centre și progresiv într-un număr de până la 9 centre în perioada 2010 2015. În ultimii 7 - 8 ani metoda este introdusă progresiv în pregătirea studenților pentru practica medicală, în și prin ecografie, în Centrul Universitar Cluj, iar conferințele includ, la inițiativa aceluiași centru, în fiecare an, câte o masă rotundă de educație în ultrasonografie.

În acest an sesiunea științifică educațională este precedată de o întrunire a CD al SRUMB, în cadrul Conferinței Naționale organizate la Tg. Mureș, în perioada 9- 11 mai 2019. Va fi astfel prezentat Proiectul Centrului Universitar Cluj pentru reformarea și actualizarea programei curriculare de pregătire pentru atestatul de ultrasonografie, respectiv Modulele I (US generală) și II (US specială) - curs și stagiu practic - manualități. Sunt incluse și dezvoltate în proiect capitole noi - în special CEUS, elastografie, "point of care ultrasonography” (POCUS) - sunt reformulate propunerile pentru durata unor cursuri și stagii, precum și pentru stagiile de manualități în ambele module. Alături de reforma curriculară, în aceeași întrunire a CD al SRUMB vor fi discutate propunerile pentru caietul de stagiu - logbook, cu propuneri de creștere a numărului de examinări efectuate/asistate de la 300 (în prezent) la 500, dar și pentru o modalitate unitară de evaluare a cursanților, în principal pe modelul examenului organizat de către Ministerul Sănătății, în prima ediție 2019, în perioada mai-iunie.

Vor fi însă aduse în discuție unele obstacole și dificultăți în organizarea procesului de formare în ultrasonografie, respectiv fluctuațiile numărului de centre disponibile pentru pregătire sau a persoanelor abilitate pentru procesul de instruire. Va fi analizată și noua configurație a profilurilor competențelor/atestatelor de ultrasonografie, respectiv atestate cu o tematică și profil restrânse, unele apărute recent, direcție se pare greu de evitat în acest proces multivalent. Vor fi de asemenea discutate modalitatea de organizare a pregătirii în rezi- dențiat în specialități care au prevăzut modulul I în pregătirea vocațională, acordarea unor adeverințe de abilități incluse în profilul specialității, organizarea continuă de către SRUMB a unor cursuri de perfecționare în practica noilor aplicații ale ultrasonografiei. CD va propune înființarea unor grupuri de lucru pentru analiza tuturor propunerilor și armonizarea lor cu experiența europeană în domeniu, dar și cu condițiile de punere în practică în România.

Tradiția românească de practică a ultrasonografiei de aproape 45 de ani, aplicațiile ei și procesul de formare inițiat în numeroase specialități de aproape 30 de ani, vârsta tânără de 22 de ani, matură însă, a SRUMB, fondată în 1997 și, mai ales, profilul clinic al practicii ultrasonografiei, "stetoscop" din ce în ce mai performant pentru diagnosticul medical complex și terapia ghidată sunt certitudini și argumente pentru care SRUMB va avea o preocupare continuă și va depune eforturi susținute de dezvoltare. Astfel organizarea la Timișoara, capitala culturală europeană, în 2021a Congresului Mondial de Ultrasonografie va fi, atât pentru organismele internaționale, cât și pentru societatea noastră un prilej de confirmare a acestor eforturi.

8 mai 2019

Prof. Viorela Enăchescu

Președinte executiv al SRUMB (2018 - 2020) 